\title{
Empowering smallholder rice farmers in Tanzania to increase productivity for promoting food security in Eastern and Southern Africa
}

\author{
Costancia Peter Rugumamu
}

\begin{abstract}
Background: Despite low rice yield levels in Tanzania, the country is the leading producer in Eastern and Southern Africa. Given that this business is dominated by smallholder farmers and that the country is endowed with extensive landscapes suitable for rice production coupled with a high domestic and foreign potential market, there is an urgent need to enhance the yield as a key to promote food security from household to national and international levels. This paper seeks to demonstrate the importance of empowering smallholder farmers as a strategy for identifying and applying improved rice husbandry technologies in a holistic and integrated manner by employing a Farmer Field School (FFS) approach.
\end{abstract}

Methods: The study was conducted in two sample villages, namely Kipera Njiapanda in the Morogoro region and Bwawani Visegese in the Pwani region, where culturally and ecologically rice is grown. The FFS approach was applied with the involvement of smallholders and local authorities to develop innovative ways to increase yield and promote food security. Data and information on current rice farming practices were collected using FFS participants and qualitatively analyzed at each rice production stage.

Results: Findings revealed that farmers' socioeconomic conditions varied, thus reflecting differences in farm size, crop husbandry and associated yield as well as in non-market production along with consumption and/or market exchange. The FFS approach demonstrated that community participatory processes have the capacity to create conducive conditions for empowering smallholders to identify their rice production problems and opportunities related to access to technical and financial support in the realm of seedbed preparation and irrigation, including pest and disease control and crop marketing.

Conclusion: The FFS approach is a robust tool for the identification of problems/challenges as well as pertinent opportunities to increase rice yield and promote food security. The paper calls for support from development partners in managing the rice production systems at all stages in the production cycle given the current potential of both the smallholder farmers and the arable land to increase rice yield, reduce poverty and promote food security at household, national and international levels.

Keywords: Rice yield, Smallholder farmers, Farmer Field School, Technology, Food security

\section{Background}

In Tanzania, agriculture is the mainstay of the national economy, with rice being one of the major food and cash crops, as acknowledged by Agritrade [1] for being the largest rice producer accounting for about $80 \%$ of total production in Eastern Africa. Approximately 80\% of

Correspondence: wrugu@udsm.ac.tz

Department of Zoology and Wildlife Conservation, University of Dar es Salaam, PO Box 35064, Dar es Salaam, Tanzania
Tanzanians are employed in the agriculture sector, which accounts for half of the national income and three quarters of merchandise exports in the country [2]. As stated by Agritrade [1] and Kafitiriti et al. [3], the country ranks second within Eastern, Central and Southern Africa in terms of rice production and consumption after Madagascar. Despite this promising trend, it is further noted that rice production is heavily dependent on rainfall, and under good weather conditions and improved 
husbandry the country is potentially capable of achieving food self-sufficiency as measured by levels of grain production [4].

Rice is grown under three major ecosystems, namely rain-fed lowland, irrigation (or flooded conditions) and upland rice (non-flooded conditions), with each type characterized by a relatively low yet differing production potential depending on varying soil and climatic conditions [5]. Reviews of the major causes of low rice yields have been undertaken by Concern Worldwide [4], the Ministry of Finance and Economic Affairs [6], Kaburire and Ruvuga [7] and Bucheyeki et al. [8], among others. These include hostile environmental conditions due to climate change, low level and inadequate technology dissemination channels, crop pests and diseases and low yielding rice varieties as well as gender dynamics.

A number of programmes have been put in place to address some of these challenges [6,9-11]. In 2001, the Government of Tanzania launched the Agriculture Sector Development Strategy (ASDS), followed in 2003 by the Agricultural Sector Development Programme (ASDP), which was implemented at district level under the District Agriculture Development Plan (DADP) focusing on increasing agricultural productivity, profitability and farm incomes $[9,10]$.

It is in this light that the Government of Tanzania's commitment to address the food insecurity issue was reflected in the National Strategy for Growth and Reduction of Poverty phase 2 (NSGRP II) and the Millennium Development Goals (MDGs) [6]. In essence, food security refers to a state of affairs where all people at all times have access to safe and nutritious food to maintain a healthy and active life [12]. In the same vein, working in partnership with other stakeholders, such as the AfricaRice project, Tanzania deemed it mandatory to invigorate rice production in order to promote food security and increase foreign exchange earnings [13]. It is worth noting, therefore, that making progress in achieving food security calls for effective participation of stakeholders in the decisions and actions that affect their lives in the rice production chain.

In this regard, it may be stated that the existing rice production potential for increased yield and promoting food security in Tanzania has not been examined or addressed in a participatory, holistic and integrated manner. On the contrary, it is obvious that various institutions conventionally address issues pertinent to their own missions, thus overlooking the whole set of challenges faced by the farming communities. This logically implies that the identified problems are compartmentalized issues, since they are studied through inadequate understanding of the relationship between specific system components being the basis for guiding input, output and feedback.
It is against this premise that this study was carried out using a Farmer Field School (FFS) approach, as advocated by Stathers et al. [14] in order to achieve integrated rice production processes and pest and disease management to enhance yield. Smallholder farmers in Tanzania dominate the agricultural sector, with average farm sizes being between 0.9 and 3.0 hectares and cultivating 5.1 million hectares annually, of which $85 \%$ is food crops [2]. By teaming up with the smallholders in the field school situation, the thrust of the study was to improve organization and management skills by empowering the participants through education and innovative communication to make better use of their existing knowledge and resources to handle their own on-farm decisions in the full cropping season. The ultimate goal was to inculcate into the minds of smallholder farmers the best rice production practices, and hence high yield coupled with food security.

The specific objectives of the study were twofold. First, to investigate the current rice production technologies used by smallholders in order to identify attendant problems and opportunities/solutions; and second, to inform development partners of the need to empower smallholders in order to enhance yields in an integrated management approach and to improve household food security and beyond. This paper, therefore, underscores the effectiveness of the FFS approach as a tool for communicating challenges and opportunities faced by smallholder farmers and their development partners in the rice production process on one side and the researcher/facilitator on the other.

\section{Materials and methods}

\section{Selection of study area}

This field study was conducted in the Morogoro and Pwani regions of Tanzania, located to the west of the Indian Ocean (Figure 1). Four factors influenced the choice of the study areas. First, the area, extending up to about $300 \mathrm{~km}$ inland, falls within a suitable agro-ecological zone for rice production. Second, the two regions have a similar sociocultural set-up and spatially they form the hinterland of Dar es Salaam city, a major market for rice. Third, they are known to be the key rice producing regions accounting for $67 \%$ of total rice production [15] and form the largest population groups in the country with a significant portion of the local rice market. Finally, there is potential demand for rice grown in these regions due to accessibility by road networks, the Tanzania-Zambia Railway Authority (TAZARA) and the Central Railway line, as shown in Figure 1. As noted above, this means that rice from the two regions could be easily transported to the Southern African region and to most of the countries in the Lake Zone as an export crop [1]. To this end, the two model rice growing villages selected for the study are: Kipera Njiapanda in the Mvomero district, Morogoro 


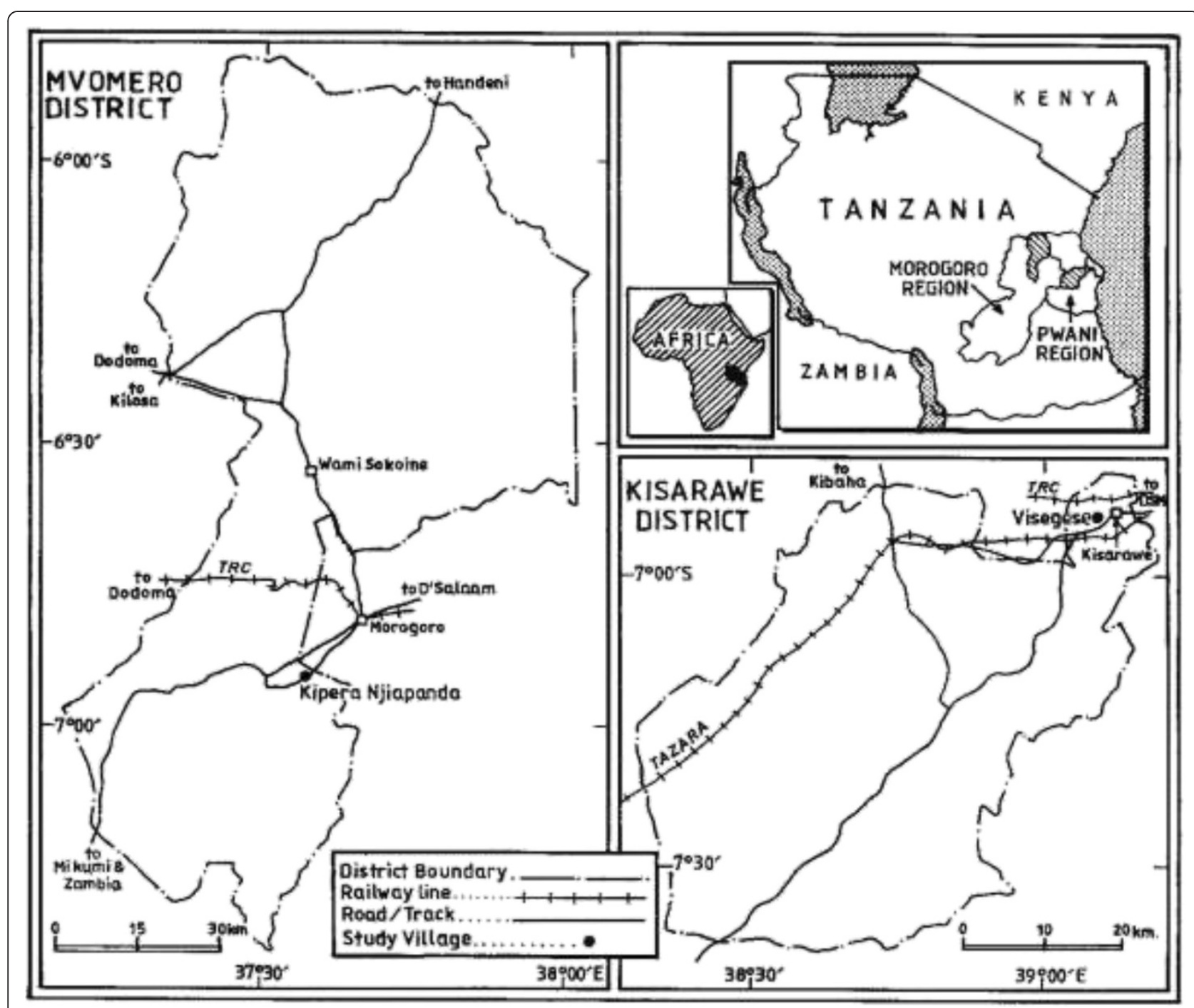

Figure 1 Location of the study areas, Kipera Njiapanda and Bwawani Visegese. Note the road and railway line networks.

region; and Bwawani Visegese in the Kisarawe district, Pwani region (Figure 1).

\section{Data collection}

Primary and secondary data sources of integrated rice production processes and management formed the basis of this study. A literature survey was conducted in order to better understand the state-of-the-art of rice farming in the country in general and attendant theories. The field study entailed participatory observation and recording and analysis of real problems and opportunities in all rice production processes and activities, from arable land ownership and selection to consumption and/or processing for the market.

A participatory approach grounded in the FFS was pursued, with 20 smallholder rice growers purposefully chosen in each of the two research villages to participate in the FFS [14]. The selection of participants was based on income levels in order to capture a representative cross-section of the communities within their socioeconomic context. Duwayri et al. [16] reported that yields vary among farmers in the same location, with good farmers usually reaping more benefits from improved technologies than mediocre farmers at the same place. The research was thus carried out during the major rice farming activities between August 2012 and June 2013 in order to better understand and verify data and information originating from the location of specific field schools and the secondary sources, as advocated by Gyawali et al. [17].

With respect to pest and disease control, the FFS participants were introduced to the management procedures. Insects and other arthropod pests and vectors of disease found on rice plants in farms were captured by employing a sweep net sampling method [18]. Sampling of all pests 
was conducted by the participants at critical phases of rice growth, particularly tillering, which is a vegetative phase, and booting and milking stages, referred to as the reproductive phase. Sampling of 30 sweeps was carried out at the centre part of the rice plots and also close to the bund (about $1 \mathrm{~m}$ ) while walking slowly through the rice plot during dew-free periods in the day [18]. Most larvae borers were sampled from plant parts as indicated by damage symptoms. Rice plants showing root-knot symptoms were sampled for investigation of nematodes. Weeds in the farms were collected for identification. Thereafter, all organisms captured were introduced in labeled plastic bags and a preliminary identification by FFS participants guided by the researcher was carried out. The samples were then preserved for detailed identification in the laboratory, according to Southwood and Henderson [18], Hill [19] and Picker et al. [20].

\section{Data analysis}

Qualitative techniques were employed to analyze the data [21]. Data and information recorded as verbal responses provided by the FFS participants were contextually analyzed to generate more complete, meaningful and useful understanding of the rice production processes.

\section{Results and discussion}

\section{Farmland setting and preparation}

The rice farm holdings were private property whereby farmers controlled their rice farm holdings. The smallholders who formed the rice FFS predominantly shared a similar socioeconomic and cultural background. The size of farm holdings varied among the participants. This was the result of the predominance of traditional technologies, namely hand tools, humus economy and household labour constraints, coupled with sporadic diseases such as malaria among family members, which contributed to labour shortage and subsequent cultivation of small plots.

The FFS members' ingenuity in Bwawani enabled them to classify their land using physical properties, as follows: 1) flat landscape unit; 2) readily seasonally flooded land;3) clayey soils; 4) predominance of luxurious grasses belonging in the rice Family Poaceae (also called Gramineae); and 5) land easily reached from the homesteads. The choice of the plot sites in floodplains was hence dependent on indigenous/traditional environmental knowledge. Members upheld that landscapes with the aforementioned attributes were scarce. Therefore, the cultivation of isolated/ fragmented plots in Bwawani reflected spatial discontinuity of soils suitable for rice cultivation.

In Kipera, all participants were members of the irrigation scheme. The land under the irrigation agriculture was limited by the small capacity of the scheme, which serves members from four sub-villages, namely Kipera Njiapanda, Kipera Mbuyuni, Kipera Kinyenzo and Kipera
Luguno, and therefore supports only about 120 farmers. Land preparation in the scheme included the repairing of canals, land and patch banding, as supported by Katambara et al. [11]. The participants also owned plots adjacent to the scheme, and the most popular traditional rice cultivation practice in those valleys was characterized by flooded rainwater.

Given that farmers in both villages predominantly used hand tools, including hand hoes, matchets, pick axes, slashers, wooden sticks and knives, they all expressed the need to access tractors to promote timely sowing with the onset of the rains and flooding of the farms, a precondition of increased yield as articulated by Katambara et al. [11]. Farmers in BwawaniVisegese expressed the desire to be enabled to access tractors through loans from the Kisarawe District Council. The farmers felt that it was viable to settle the loan after harvesting and marketing the produce. It was revealed that all available family members were involved in farm preparation,with women spending more hours on the activity than men, which reflected gender inequity in labour input. This viewpoint is supported by Leavens and Anderson [22] who reported that in Tanzania, agriculture comprises a greater part of women's economic activity than men's, whereby $81 \%$ of women compared to $73 \%$ of men are engaged in agricultural activity, while in rural areas that proportion rises to $98 \%$ for women.

Additionally, farmers called for technical support in the realm of nursery preparation, seedling production and improvement in land leveling, paddling and banding as well as canal construction, in order to improve water retention capacity for efficient seed germination and growth. Furthermore, farmers appealed to development partners to assist in the acquisition of technical knowledge on ponding rainwater for irrigation, such as dam construction (charcoal), which would ensure adequate flooding conditions and irrigation throughout the rice growing and development stages, should rain fail them (like it did in the 2011/2012 growing season). During training, it was realized by all members that rice growth and development is heavily constrained by unreliable onset, amount and distribution of rainfall. Katambara et al. [11] reported that the demand for water for irrigation in Tanzania outstrips the amount of water available for irrigation and other purposes, and that there is a need to apply appropriate technologies in the farming practices to ensure high yield while minimizing water utilization demand.

\section{Characteristics of rice seed varieties and sowing activity}

During the training sessions, the FFS participants established that seed varieties for sowing were locally acquired by recycling the previous year's harvests, purchasing from either the village markets and/or neighbours and from friends and relatives in the same or distant villages. They 
reported that the rice varieties widely grown in both villages varied and the major characteristic considered for the choice of varieties was taste. The common varieties grown in Bwawani were Machale, Supa, Borakupata, Kahogo, Tule na Bwana and Kibakuli, while in Kipera, Supa, Kahogo, Mbagara and Moshi wa Paa were grown. The varieties were grown on separate portions of farms, and choices could vary in different seasons as they were selected depending mainly on availability.

Concurring with Joshi et al. [23], the farmers demonstrated their traditional environmental knowledge of seed genetics as they reported the criteria employed in selecting good quality seeds and varieties for sowing. Their observations were further supported by Joshi et al. [23] who noted that smallholder farmers often selected crop varieties that were well-adapted in particular ecosystems. The farmers unanimously acknowledged that varieties of rice which were high yielding, aromatic and marketable coupled with grain heaviness and pest, disease and drought resistantwere the most preferred, but were often inaccessible.

In both study areas, two rice farming systems were broadly identified. In Bwawani, the sowing of maize, carried out immediately at the onset of the November/December rains, precedes that of rice, while in Kipera, tomato cultivation proceeds rice harvesting by capitalizing on the residual soil moisture. These systems were conceived as strategies for food security in the areas. The participants emphasized that sowing early at the onset of rains allowed an adequate amount of water for a desirable period and hence a good harvest. They narrated their experience of a 2- to 3-week drought after sowing which resulted in a low rice yield, a feature that underscores the need for installation of irrigation infrastructure to meet the moisture deficit.

The FFS participants affirmed the practice of two types of sowing rice, namely drill and broadcast sowing. The former type employed uniquely small hand hoes and wooden sticks that lead to desirable patterns and spacing. Establishing nurseries was advocated in order to maximize the utilization of the available arable land for increased yield. They further noted with concern the labour demand at this stage of rice production, appealing for support to access improved rice sowing technology based on the tillering capacity of a particular rice variety.

\section{Management of pest infestation and disease infection}

FFS participants shared their knowledge regarding pest attacks and diseases which reduce rice yield. Weed pest control was considered by all members of the FFS to be one of the determinants of high rice yield. The common weeds collected and co-identified by both common and scientific names in both villages included 'Kongwa', Monochoria vaginalis, and 'Ndago', Cyperus iri. As noted by Euroconsult [24], the facilitator emphasized that two to three weeding operations should be mandatory until crop maturity. As an integrated weed pest control strategy, it was highlighted and noted that an adequate floodwater layer was the most appropriate technology for controlling weeds because few plant species can tolerate flood conditions.

Together with the facilitator, insect pest species were identified as belonging predominantly in the Order Lepidoptera (Table 1). The identified insects were among those reported by Sehgal et al. [25] who illustrated that the rice crop can be attacked from the seedling stage through to harvest and storage. Members appreciated the fact that insects attack different parts of the rice plant and that this depends on the type of their mouth parts. It was made clear, for instance, that adult and nymph hemipterans use their piercing and sucking mouth parts, and lepidopteran and Diptera larvae and adult and nymph orthopterans damage plant parts by using their biting and chewing mouth parts. Thus, the insects were conceived to be stem/stalk borers, stem and root feeders and leaf and panicle feeders as well as suckers, extracting liquid known as milk from grains and saps from leaves (Table 1). It was made clear to the members during field investigations that sucking insect vectors spread disease viruses, which turn

Table 1 Insect pests and disease vectors of rice identified in FFS farms in the study areas

\begin{tabular}{|c|c|c|c|}
\hline Common name & Species & Order/family & Pest/vector \\
\hline Spotted stalk borer & Chilo partellus Swinh. & Lepidoptera/Pyralidae & $\begin{array}{l}\text { Pest: larvae feed in the leaf funnel and the dead central } \\
\text { leaves form 'dead heart'. }\end{array}$ \\
\hline White stem borer & Maliarpha separatella Rag. & Lepidoptera/Pyralidae & Pest: larvae bore stem. \\
\hline Pink stalk borer & Sesamia calamistis Hmp. & Lepidoptera/Noctuidae & Pest: larvae bore stem. \\
\hline Stalk-eyed fly & Diopsis thoracica West. & Diptera/Diopsidae & Pest: maggots eat the central shoot and flower head. \\
\hline Rice stem gall midge & Orseolia oryzae W.M. & Diptera/Cecidomyiidae & $\begin{array}{l}\text { Pest: maggots feed at base of the growing shoot causing } \\
\text { the formation of a tuber gall. }\end{array}$ \\
\hline Hispid beetle & Trichispa sericea Gn:; Dactylispa lenta & Coleoptera/Chrysomelidae & $\begin{array}{l}\text { Pest: cause severe defoliation; vector: of rice yellow } \\
\text { mottle virus (RYMV). }\end{array}$ \\
\hline Small rice grasshopper & Oxya chinensis Thnb. & Orthoptera/Acrididae & Pest: adults eat foliage and panicle; nymph eats foliage. \\
\hline Green stink bug & Nezara viridula L. & Hemiptera/Pentatomidae & $\begin{array}{l}\text { Pest: punctures and feeds on young seed; } \\
\text { vector:spread fungi. }\end{array}$ \\
\hline
\end{tabular}


leaves to brown and spotty, a condition frequently observed in their farms.

The FFS groups became aware that damaged leaves result in a low rice yield because the reduced surface area of the leaves lessen their capability to produce food by photosynthesis. These implications are well collaborated by Matteson [26] who reported that plants refill their grains after early attacks, but the rice plant cannot recover from later attacks and the resultant rice yield becomes contaminated by bacteria or fungi injected into the grains by infected insects, and that such harvests are called 'pecky rice'. This knowledge instilled into the participants the sense to undertake rapid control measures.

The group members revealed that rodents were controlled by using baited traps, while birds were scared by throwing stones and sticks as well as erecting human dolls of various shapes and sizes. These measures were undertaken immediately at the onset of the reproductive phase through to ripening and maturity and up to harvesting in 'programmed' rotations. An interesting technology observed in Kipera was the hanging of cassette ribbons across farm plots, which when blown by the wind produced noise that scared birds. The activity was deemed to be labour intensive. It was also observed that water snails occurred rarely, and that these pests cut stems or leaves in young rice plants. It was confirmed by members that control was by physical destruction. According to Sehgal et al. [25], this approach could be a palliative measure because in the presence of water females have a high reproductive performance.

During observations of the rice roots, participants noted that some had swelling tips. Further investigation revealed the occurrence of root-knot nematodes, Meloidegyne graminicola, as rare pests that cause the swelling of root tips. It was explained by the facilitator that such a condition causes disruption and hypertrophy of the root cortex resulting in stunted plants with chlorotic leaves.

Sporadic armyworm outbreaks were reported in Bwawani, where farmers inform government authorities for intervention. In the event of delayed response, they immediately purchase chemical pesticides from local business persons. However, it was underscored that often such chemicals proved ineffective. Another pest control strategy introduced to members of the FFS was cultivating two or more plant species in the vicinity of rice plots to provide alternative hosts for some pests and vectors, and thus to reduce damage levels. According to Abate et al. [27] and Heinrichs and Barrion [28], such diverse traditional cropping systems enhance natural enemy abundance and generally keep pest numbers below economic injury levels (EILs). It was also reported by Matteson [26] that most rice pests are controlled by a complex and rich web of generalist and specialist predators and parasites that live in or on the rice plant, paddy water or soil. Although rare, thefts were cited to occur in both villages when the crop was ripe as well as during harvesting, drying and/or storage in homesteads.

The members and facilitator emphasized the intensification of the existing control practices as well as the utilization of acquired knowledge and skills to develop appropriate technology components in an integrated management approach. The participants expressed confidence and were empowered to rapidly identify pests at different post-embryonic development stages and also the damaging stages as well as specific parts attacked. Such skills were deemed necessary to enable farmers to apply various timely components of Integrated Pest Management (IPM) control methods and to keep the pests and vectors below EILs.

\section{Application of fertilizers}

Members of FFSs in both villages were knowledgeable that industrial fertilizer application increases rice yield, yet considered it to be very expensive. They were aware of urea and calcium ammonium nitrate fertilizers and also cow dung. The participants and facilitators thus clearly expressed the inter-linkages of fertilizer-soil-water management to avoid the risk of fertilizers being washed away by seasonal floods.

\section{Rice harvesting and transportation}

The harvesting of rice was carried out between May and August depending on the ripening status of the crop, that is, exactly when the crop has attained physiological maturity and there is no further addition of dry matter. Most participants in both villages owned simple tools. Sickles and small knives were used for separating panicles from rice plants to be collected in baskets and/or mats. Wooden sticks were used for thrashing panicles to remove paddy, which was spread on mats for initial sun drying.

Subsequently, the harvested crop, having been carefully packed in baskets, bags (polythene) and even wrapped in pieces of cloth, was immediately transported to the homesteads. In Kipera, hired trucks, bicycles and wheelbarrows were used to transport the crop, while in Bwawani trucks were hired only by farmers residing in Kisarawe town and Dar es Salaam city. Moreover, some farmers carried the harvest on their heads and/or shoulders, which was not a rare phenomenon. Harvesting and transportation were conceived to be one of the tedious activities that calls for extra labour, where the demand is always dictated by the yield.

\section{Rice yield}

At their homesteads, FFS farmers spread paddy on large mats to dry in the open air to attain a locally acceptable moisture content level of the crop as tested by experienced farmers. Thereafter, paddy was weighed and packed. It became evident during discussions in both study villages 
that there were varying production levels and indeed yields. The FFS participants in both villages reported that the yields obtained by the smallholder farmers for the past 3 years using the itemized technologies were varying and fluctuating. In Bwawani Visegese village, the well-to-do farmers had yields varying between 20 and 30 bags of 120 $\mathrm{kg}$ each, while the middle group had between 10 and 20 bags and the poor produced between 1 and 5 bags per hectare (Table 2). The estimated average rice yield in the small irrigation scheme in Kipera Njiapanda was 12 bags per hectare. The members were optimistic about gaining increased rice yields once the learnt technologies and innovations could be applied in an integrated manner.

\section{Storage of paddy}

FFS members aware of post-harvest crop losses had invented traditional storage technologies to minimize damage and/or losses. This culture was also reported by Rugumamu [29] in the maize storage systems in Tanzania. In both villages, farmers used locally constructed containers and polythene bags which were placed on raised platforms, a method deemed to retain the required level of moisture content of the crop and protect from rodent attack. In this phase, the FFS farmers expressed concern and care that they attached to the harvest in order to minimize post-production losses, which have a direct bearing on food security. They articulated the need for constructing improved warehouses/godowns for storage of paddy as a means of increasing the safe storage period.

\section{Marketing of rice}

The production of rice in the two villages was predominantly for subsistence and hence a small proportion was sold to meet other basic needs. In the course of discussions, the members in Kipera observed that economic liberalization was already in place as farmers readily sold their commodity at their weekly local markets. Given the advantageous geographical location and relatively high yield, large quantities of rice and/or paddy were purchased by petty traders who re-sold them to businessmen and women from the Morogoro municipality and metropolitan Dar es Salaam. These are the transactions that form the start of the international rice trade.

Like in other areas in Tanzania [1], it was observed that marketing of the available rice was highly fragmented,

Table 2 Estimated average rice yield ( $\mathrm{kg} / \mathrm{ha}$ ) for 3 years among three socioeconomic groups of smallholder farmers in Bwawani Visegese village

\begin{tabular}{lc}
\hline Group of farmers & Rice yield $\mathbf{( k g / h a )}$ \\
\hline Well-to-do & 2,400 to 3,600 \\
Middle & 1,200 to 2,400 \\
Poor & 120 to 600 \\
\hline
\end{tabular}

with millers and brokers playing a central role in the trading process. Ultimately, as reported by the Tanzania Agricultural Partnership [9], the supply channels are generally long and the produce changes many hands before reaching the final consumer. The FFS members and facilitator, supported by Kaburire and Ruvuga [7], believed that any significant improvement in the incomes of subsistence farmers accruing from improved agricultural production and productivity would have significant backward and forward linkages to the rest of the economy. Such multiplier effects resulting from increased purchasing power of farmers for agricultural inputs, outputs and services from other sectors, and from increased supplies of food and other farm products, would help to lower the cost of living for both rural and urban dwellers.

\section{Conclusions}

In order to effectively engage communities in achieving household food security and beyond, it is deduced in this paper that participatory learning processes through FFSs have the capacity to create conducive conditions for empowering smallholder farmers to identify problems and propose opportunities/solutions directed towards increased yield. In a nutshell, the approach has been able to raise community awareness about revitalizing the rice production cycle in a holistic and integrated manner within the improved socioeconomic and ecological production set-up. The knowledge and skills gained and shared among and between the smallholder farmers and their development partners during the FFSs at each stage of the rice production cycle, when integrated, form tools for implementation and dissemination of appropriate technologies required to enhance yield and promote food security.

To this end, it is proposed that the next research agenda will be to explore the implementation of the identified technologies in the study villages in order to form a platform to monitor and evaluate the impact of training to improve rice yields for FFSs. The output will provide demonstration avenues for other rice producing communities of western and southern Tanzania, where the industry is gaining momentum in terms of increased yield to meet both domestic consumption and market demand.

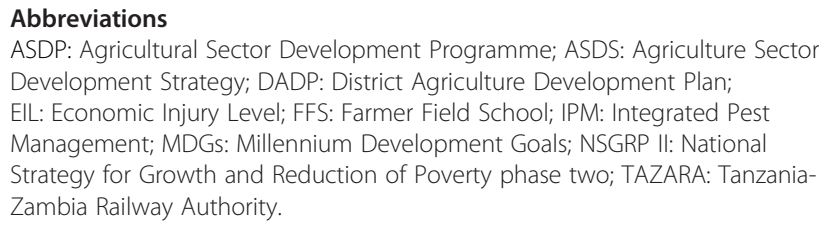




\section{Author's information}

Academically, CPR holds a B.Sc. (biological sciences and education), M.Sc. (Applied Zoology) and Ph.D. (Applied Zoology). CPR is a Senior Lecturer and specialist in crop pest management. CPR is currently the Dean at the Faculty of Science, Dar es Salaam University College of Education. CPR is a Fellow of the Tanzania Academy of Sciences and Chairperson for the Association of Science Technology and Innovation for Women in Tanzania. CPR has been serving in different boards, including the Board of the National Museum of Tanzania as a Chairperson.

\section{Acknowledgements}

This paper benefited from generous support provided by individuals, groups and institutions. The author is grateful to the Gender Centre of the University of Dar es Salaam for facilitating the final development of the research proposal. The author also wishes to pay tribute to the Dar es Salaam University College of Education for availing a four-wheel drive vehicle and a driver for ease of transport in the study villages. Finally, the author wishes to record sincere appreciation to the smallholder farmers, local leaders and extension staff who diligently participated in the FFSs.

Received: 11 January 2014 Accepted: 24 March 2014

Published: 21 April 2014

\section{References}

1. Agritrade: USDA Review of Policy Constraints on Competitive EAC Rice Production: News and Analysis. Wageningen: CTA; 2012.

2. United Republic of Tanzania: (URT) Agricultural Sector Development Programme Performance Report. Dar es Salaam: Government of Tanzania; 2011.

3. Kafitiriti EM, Dondeyne S, Msomba S, Deckers JA, Raes D: Variations in agronomic characteristics of irrigated rice varieties: lessons from participatory trials in South Eastern Tanzania. Food Agric Environ 2003, 1:273-277.

4. Worldwide C: Responding to the Needs of Marginal Farmers: A Review of Selected District Agricultural Development Plans in Tanzania. London: Concern Worldwide; 2008.

5. Kato F: Development of major rice cultivation area in the Kilombero Valley Tanzania. Afr Study Monogr 2007, 36:3-18.

6. Ministry of Finance and Economic Affairs: National Strategy for Growth and Reduction of Poverty II (NSGRP II): Policy. Dar es Salaam: Ministry of Finance and Economic Affairs, United Republic of Tanzania; 2010.

7. Kaburire L, Ruvuga S: Networking for agricultural innovation. MVIWATA national network of farmers' groups in Tanzania. Bull 2006, 374:80-86.

8. Bucheyeki TL, Shennkalwa E, Kadadi D, Lobulu J: Assessment of rice production constraints and farmers preferences in Nzega and Igunga districts. J Adv Dev Res 2011, 2(1):30-37.

9. Tanzania Agricultural Partnership: Value Chain Analysis of Rice and Maize in Selected Districts in Tanzania: Report. Dar es Salaam: Agricultural Council of Tanzania/Tanzania Agricultural Partnership; 2010

10. Vermeulen S, Cotula L: Making the Most of Agricultural Investment: A Survey of Business Models that Provide Opportunities for Smallholders: Report. IIED/ FAO/IFAD/SDC: London/Rome/Bern; 2010

11. Katambara Z, Kahimba FC, Mahoo HF, Mbungu WB, Mhenge F, Reuben P, Maugo $M$, Nyarubamba $A$ : Adopting the system of rice intensification (SRI) in Tanzania: A review. AgricSci 2013, 4:369-375.

12. Food and Agriculture Organization of the United Nations (FAO): World Food Summit: Food for All. Rome: FAO; 1996.

13. Lugongo B: Tanzania government unveils strategy to triple rice output. Citizen Newspaper 2010.

14. Stathers T, Namanda S, Mwanga ROM, Khisa G, Kapinga R: Manual for Sweet potato Integrated Production and Pest Management Farmer Field Schools in Sub-Saharan Africa. International Potato Center: Kampala; 2005.

15. Afari-Sefa V, Beed F: Enhancing Vegetable Value Chains in Rice-Based and Sole Crop Production Systems to Improve Household Income and Consumption in Morogoro. Presented at Africa RISING East and Southern Africa Research Review and Planning Meeting, Arusha, Tanzania, 1 to 5 October 2012. AVRDC, The World Vegetable Center: Tainan; 2012.

16. Duwayri M, Van Tran D, Nguyen VN: Reflections on Yield Gaps in Rice Production: How to Narrow the Gaps. Rome: Food and Agriculture Organization of the United Nations (FAO); 2003.
17. Gyawali S, Sunwar SS, Ubedi M, Tripathi M, Joshi KD, Witcombe JR: Collaborative breeding with farmers can be effective. Field Crop Res 2007, 101:88-95.

18. Southwood TRE, Henderson PA: Ecological Methods. 3rd edition. Wiley-Blackwell: Hoboken, NJ; 2000.

19. Hill DS: Pests of Crops in Warmer Climates and their Control. Berlin: Springer; 2008.

20. Picker M, Griffiths C, Weaving A: Field Guide to Insects of South Africa. Cape Town: Struik Publishers; 2004.

21. Marshall C, Rossman GB: Designing Qualitative Research. 4th edition. London: Sage Publications; 2006.

22. Leavens MK, Anderson CL: Gender and agriculture in Tanzania. EPAR Brief 2011, 134:1-14

23. Joshi KD, Musa AM, Johansen C, Gyawali S, Harri D, Witcombe JR: Highly client-oriented breeding using local preferences and selection produces widely adapted rice varieties. Field Crop Res 2007, 100:107-116.

24. Euroconsult (Eds) (Ed): Agricultural Compendium for Rural Development in the Tropics and Subtropics. 3rd edition. Oxford: Elsevier; 1989.

25. Sehgal M, Jeswani MD, Kaira N: Management of insect, disease and nematode pests of rice-wheat in the indo-gangetic plains. $J$ Crop Prod 2001, 4(1):167-226.

26. Matteson PC: Insect pest management in tropical Asian irrigated rice. Annu Rev Entomol 2000, 45:549-574.

27. Abate T, van Huis A, Ampofo JKO: Pest management strategies in traditional agriculture: an African perspective. Annu Rev Entomol 2000, 45:631-659.

28. Heinrichs EA, Barrion T: Rice-Feeding Insects and Selected Natural Enemies in West Africa: Biology, Ecology, Identification. International Rice Research Institute: Metro Manila; 2004.

29. Rugumamu CP: Assessment of post-harvest technologies and gender relations in maize loss reduction in Pangawe village eastern Tanzania. Tanz J Sci 2009, 35:67-76.

doi:10.1186/2048-7010-3-7

Cite this article as: Rugumamu: Empowering smallholder rice farmers in Tanzania to increase productivity for promoting food security in Eastern and Southern Africa. Agriculture \& Food Security 2014 3:7.

\section{Submit your next manuscript to BioMed Central and take full advantage of:}

- Convenient online submission

- Thorough peer review

- No space constraints or color figure charges

- Immediate publication on acceptance

- Inclusion in PubMed, CAS, Scopus and Google Scholar

- Research which is freely available for redistribution

Submit your manuscript at www.biomedcentral.com/submit
C Biomed Central 